\title{
PERFORMANCE OF OIL PALM LOOSE FRUITS SEPARATING MACHINE
}

\section{MOHD RAMDHAN KHALID* and ABD RAHIM SHUIB*}

\begin{abstract}
Oil palm loose fruits contain a high amount of oil, hence they need to be fully collected. Handpicking may be the ideal way to get clean fruits but this practice is inefficient. Raking is a faster option to gather scattered fruits but the trash that comes together during the gathering process is high. The oil palm loose fruits separating machine offers a mean to separate loose fruits from trash using vibration and airstream principles. Parameters that were observed included productivity, time-motion, loose fruits cleanliness and noise levels produced by the machine. It was observed that the machine was able to separate the loose fruits from the trash effectively with $98.9 \%$ cleanliness and at the productivity of $30.6 \mathrm{~kg}$ of clean loose fruits in 99.9 s. However, the machine produced a sound level above $90 \mathrm{~dB}$ during operation, hence, the use of personal protective equipment (PPE) is required. With the introduction of separating machine, it is anticipated that the productivity of the current collection of loose fruits can be increased, hence, contribute to higher national oil extraction rate (OER).
\end{abstract}

Keywords: oil palm, loose fruits, separating machine.

Date received: 31 March 2017; Sent for revision: 1 April 2017; Received in final form: 3 August 2017; Accepted: 4 August 2017.

\section{INTRODUCTION}

A cost-effective loose fruits collection system remains a great challenge to oil palm estates. Several prototypes of loose fruits collecting machine have been developed, however the acceptance by the industry is still limited due to several reasons such as technical limitations as well as high cost. In 2012, Abd Rahim et al. (2012) developed a loose fruits collecting machine using vacuum suction concept. Although the productivity seems to be promising but the machine is yet to be commercially available. Therefore, despite the high percentage of debris, manual raking is still widely practiced. Referring to Table 1, the advantage of raking is in the speed of loose fruits recovery, particularly during periods extended harvesting rounds due to labour shortage (Amirshah and Hoong, 2003).

Malaysian Palm Oil Board,

6 Persiaran Institusi, Bandar Baru Bangi,

43000 Kajang, Selangor, Malaysia.

E-mail: ramdhan@mpob.gov.my
Debris content in raking activity is around 30\% (Amirshah and Hoong, 2003; Darius and Fairulnizam, 2014) and can be as high as $60 \%$ by weight (Ahmad et al., 1995). Hence, there is a need to get rid of the debris before the loose fruits are sent for processing. The goal of having clean loose fruits before sending them to the mill is to get a higher oil extraction rate (OER). A large amount of trash will affect the mill productivity, as trash will absorb oil, hence, resulting in the reduction of OER. Penalty will be given to the estate if a large quantity of trash is sent to the mill together with the loose fruits. However, with the new loose fruits collection system via the introduction of loose fruits separating machine, the high percentage of debris can be reduced to an acceptable level (Figure 1).

Separation of loose fruits from debris can be done at the field (mobile type) or centralised at the collection point (stationary type). Gemka (2017) has developed a machine for separating loose fruits from debris using a rotating drum with air blast system. With a $6 \mathrm{hp}$ diesel engine, the machine was able to produce approximately $1.5 \mathrm{t} \mathrm{hr}^{-1}$ clean loose 
TABLE 1. PRODUCTIVITY OF WORKERS WITH DIFFERENT LOOSE FRUITS COLLECTION SYSTEMS

\begin{tabular}{|c|c|c|c|}
\hline & Hand picking* & Raking* & Machine $^{* *}$ \\
\hline Worker ratio $\left(\right.$ ha $\left.^{-1}\right)$ & $1: 18$ & $1: 26$ & n.a. \\
\hline Debris content & $2.5 \%$ & $30 \%$ & $<15 \%$ \\
\hline $\begin{array}{l}\text { Productivity } \\
\left.\text { (ha day }^{-1} \text { team }^{-1}\right)\end{array}$ & 25 & 31 & n.a. \\
\hline $\begin{array}{l}\text { Worker's output } \\
\left(\mathrm{kg} \mathrm{man}^{-1}\right)\end{array}$ & 177 & 273 & 500 \\
\hline
\end{tabular}

Source: *Amirshah and Hoong (2003); ${ }^{* *}$ Abd Rahim et al. (2012).

fruits. Ahmad Zamri and Mohd Zulfahmi (2017) invented a mobile type machine that utilised a layer of rotating drums with variable speeds to segregates debris from loose fruits with minimal damage.

With the separating machine, it is anticipated that the productivity of the current collection of loose fruits can be increased since the workers are now able to collect loose fruits without having to consider the amount of debris that they are picking up. Then the mixtures will be separated using the loose fruits separating machine.

\section{MATERIALS AND METHODS}

\section{The Separating Machine}

The separating machine used in this study is a mobile type hence, it can be moved from one place to another (Figures 2 and 3 ).

The separating process was done via two methods of separation: (1) vibrating tables, and (2) a blowing mechanism. The upper vibrating table, lower vibrating table and the twin fans were coupled directly to an engine via belts and pulley systems. General specifications of the machine are shown in Table 2.

During the operation, the operator pour the bags of loose fruits into the feeding compartment or the receiving hopper, and clean loose fruits will be collected at the end of the second vibrating table. The feeding compartment acts as a first separating mechanism throughout the separating processes by retaining materials larger than the loose fruits from going through the feeding compartment. The feeding compartment can be

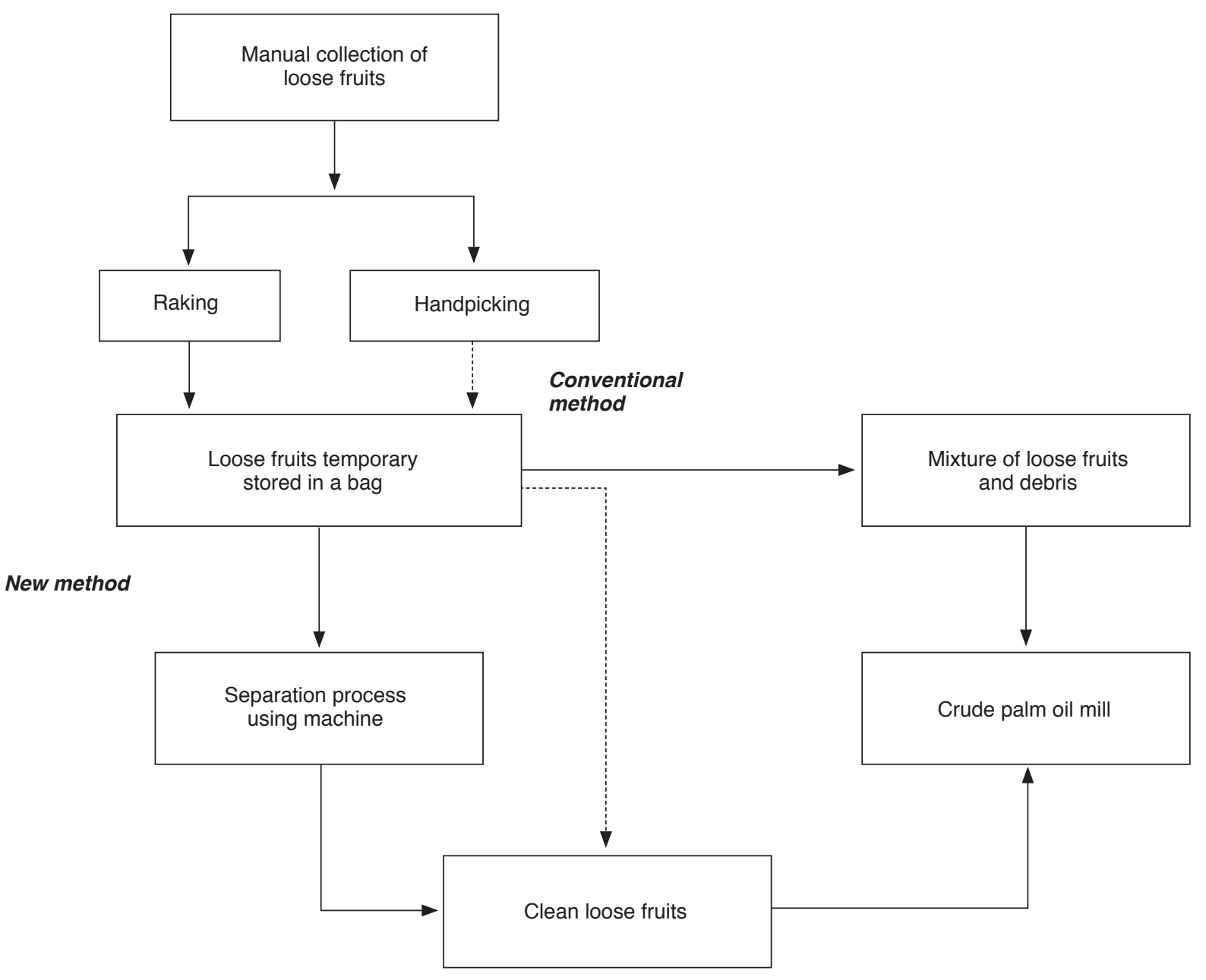

Figure 1. Flow chart of loose fruits collection system using conventional and new methods. 


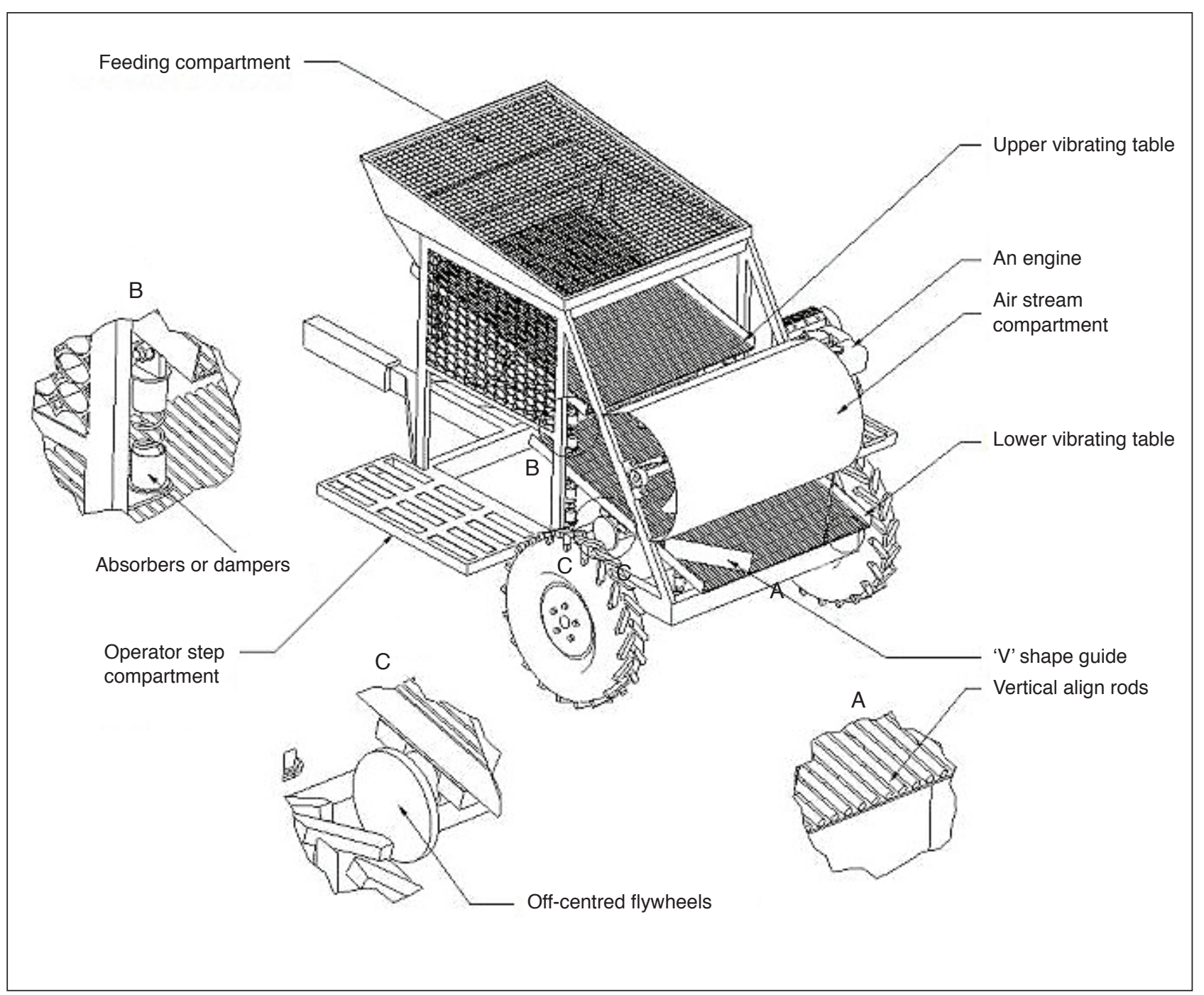

Figure 2. Isometric view of the loose fruits separating machine.

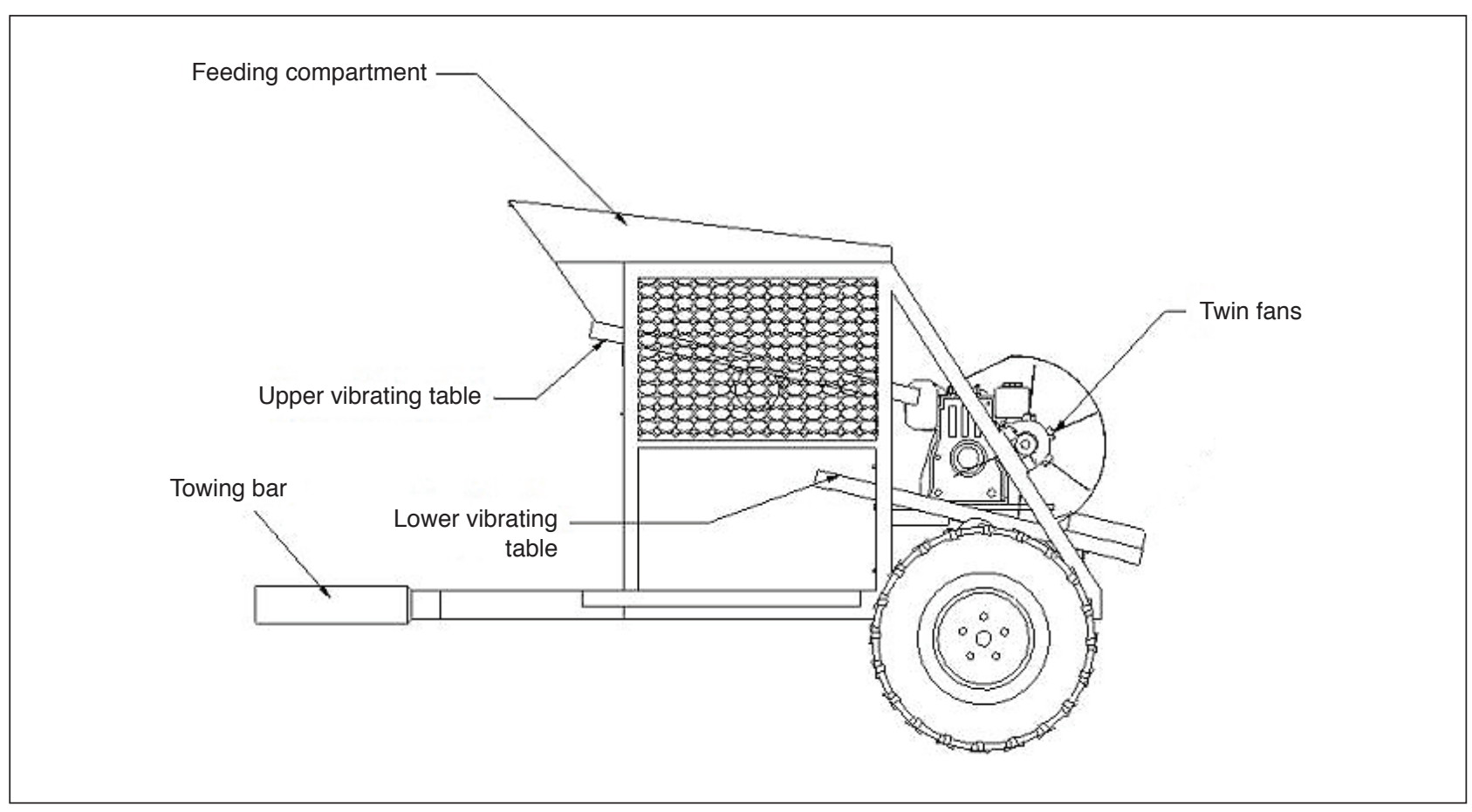

Figure 3. Side view of the loose fruits separating machine. 
manually folded up to remove the stacked debris on it.

The upper and lower vibrating tables consist of parallel aligned rods that are designed in such a way as to allow the debris (smaller than the loose fruits) to fall down between the gap. The gap between the aligned rods is calculated based on the optimum size of the loose fruits. The high-velocity air stream is created by the twin fans to blow out the lighter materials such as dried leaflets, small stones, etc. directly between the upper and lower vibrating tables.

TABLE 2. SPECIFICATIONS OF THE OIL PALM LOOSE FRUITS SEPARATING MACHINE

\begin{tabular}{lc}
\hline \multicolumn{1}{c}{ Items } & Specifications \\
\hline Engine & 6 hp air-cooled diesel \\
Overall dimension $(\mathrm{mm})$ & $2800(\mathrm{~L}) \times 1100(\mathrm{~W}) \times 1600(\mathrm{H})$ \\
Dry weight $(\mathrm{kg})$ & 250 \\
Fan & 2 units axial fan $(6$ blades each $)$ \\
Feeding capacity $(\mathrm{kg})$ & 30 \\
Tyres & $6.70 \times 15$ \\
\hline
\end{tabular}

\section{Productivity and Cleanliness}

Collection of loose fruits was done manually using a raking and bag method. Bags of loose fruits were weighed before (W1) and after (W2) the cleaning process (Table 3). Time to complete the operation for each bag was taken (T1). After that, the remaining trash in the bag was manually removed and the bag was weighed again (W3). Three samples (bags) per day were collected randomly for three consecutive days. The trials were conducted during a sunny day (no rain occurred on the previous day). The speed of the engine was maintained at $1000 \mathrm{rpm}$ during the separation process and the air velocity produced by the fan was at approximately $10 \mathrm{~m} \mathrm{~s}^{-1}$ at $1600 \mathrm{rpm}$.

\section{Sound Level Measurement}

The sound level test was conducted to ensure that the operators of this machine are not exposed to high noise levels during their working hours which may be hazardous in the long-term. Some noise level examples are $60 \mathrm{~dB}$ (normal conversation) to $120 \mathrm{~dB}$ (fire crackers). In general, sounds above $85 \mathrm{~dB}$ are unsafe, subjected to the period of the exposure. For this machine, a higher noise is expected due to the movement of the vibrating tables.

Initially, off-centred flywheel mechanism was used to create the vibrating movement of the vibrating beds, however, the vibration produced was not sufficient. Therefore, a crankshaft mechanism was used to replace the off-centred flywheel mechanism with the purpose of generating more vibration movement (Figure 4). The vibrating action was improved but it created too much noise as the metal parts brushed against each other during the rotation. To reduce the level of noise, one of the metals was replaced with a high-grade synthetic material (Teflon). Apart from using Teflon, other modifications were made such as dismantling the crankshaft at the second vibrating table and optimising the table angle, inclined at $16^{\circ}-19^{\circ}$.

Measurement of noise levels was conducted in an open area (no obstacles within $10 \mathrm{~m}$ radius from the machine) using the Sound Level Meter (Brüel and Kjár: 2238 Mediator) at six different locations around the machine, before and after the modifications (Figure 5). Three readings were collected at a distance of $30 \mathrm{~cm}$ from each location. The accuracy of measurements was within $\pm 2 \mathrm{~dB}$.

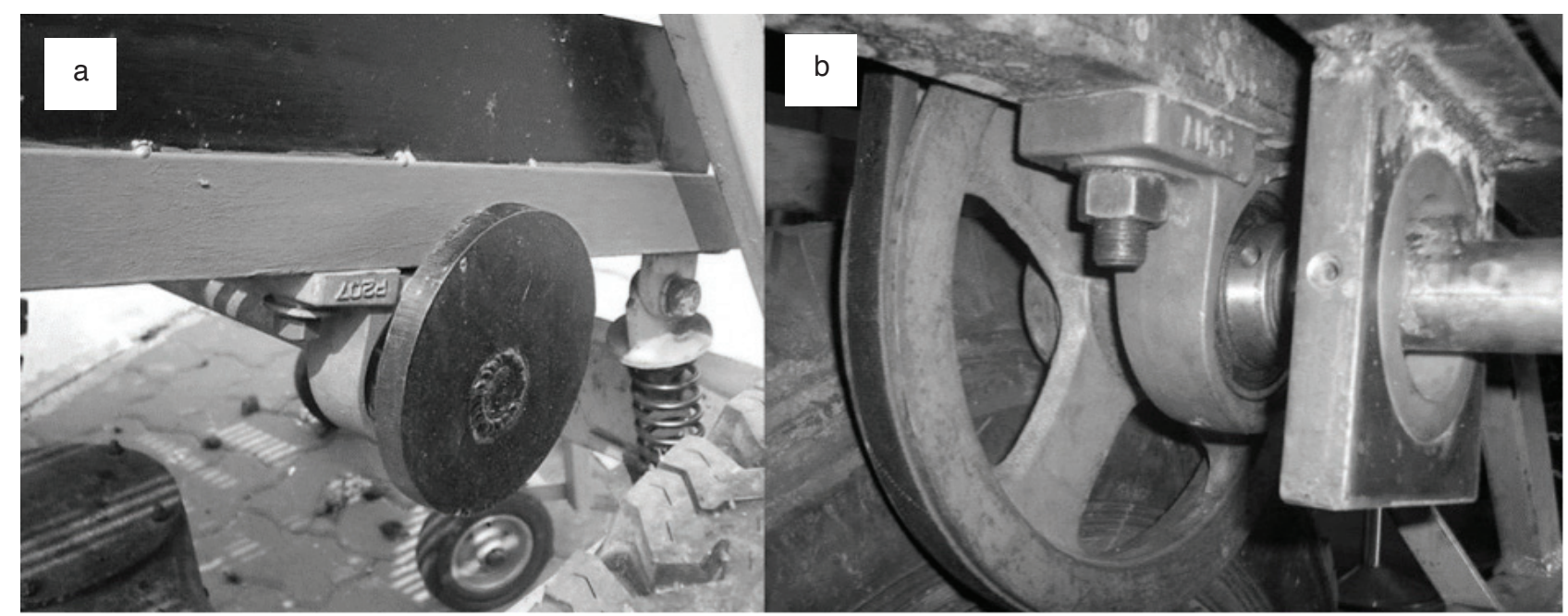

Figure 4. Vibrating mechanism was changed from (a) off-centred flywheel to (b) crankshaft system. 


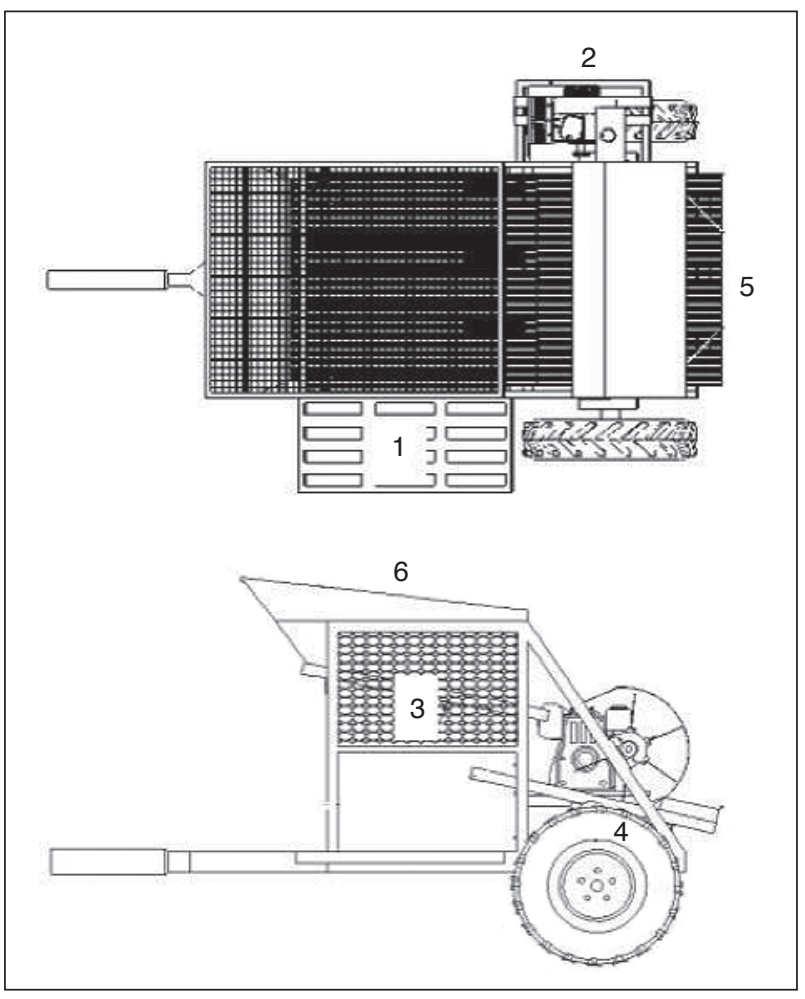

Figure 5. Points of sound level measurement.

\section{Cost-effectiveness}

Based on the productivity, the cost analysis was done to find the operating cost of the machine. The cost is calculated using the formula below:

Machine cost $=$ total fixed costs (interest in capital, depreciation, tax) + total variable cost (fuel, repair and maintenance, labour)

\section{Data Analysis}

All the statistical analyses were performed using SAS package version 9.4.

\section{RESULTS AND DISCUSSIONS}

\section{Productivity}

Table 3 shows that the machine is able to separate an average of $3.4 \mathrm{~kg}$ of debris from $30.6 \mathrm{~kg}$ of loose fruits in an average time of $99.9 \mathrm{~s}$. The table also shows that the average total of debris is $3.4 \mathrm{~kg}$ $\mathrm{bag}^{-1}$ or $11 \%$ debris weight per bag. This amount is much lower than what were reported by Amirshah and Hoong (2003); Darius and Fairulnizam (2014), i.e. $30 \%-35 \%$. The variations may be contributed by good estate management practices such as keeping a clean palm circles from vegetation. It reduces debris accumulation and avoid possibility of loose fruits from not being collected.

The study also indicates that the average remaining debris left after using the separator machine is $0.3 \mathrm{~kg}$ or $1.1 \%$. Hence, this machine is capable of providing a cleanliness level of loose fruits at $98.9 \%$. Most of the remaining debris were small stones with similar sizes to the loose fruits. With only $1.1 \%$ debris remained, comparatively it is better than manual picking method, which contained $2.5 \%$ debris (Amirshah and Hoong, 2003). From the observation, the loose fruits damage or bruising is minimum as there is no contact between fan and loose fruits.

From this study, the machine is able to separate $30.6 \mathrm{~kg}$ of loose fruits in $99.9 \mathrm{~s}$ or an estimation of $1 \mathrm{t} \mathrm{hr}-1$. This productivity is gained by using a bag-to-bag method where the operator needs to pour one bag of loose fruits at one time. He had to step down and collect the clean loose fruits in the receiving bag and subequently place a new empty bag into its position before repeating the pouring process again. This method is time-consuming but is suitable to be used in the field at the fresh fruit bunches (FFB) or loose fruits collection point. The clean loose fruits in the bags can then be collected via mainline transportation direct to the mill.

Another alternative method is to place the machine permanently at a certain height from the ground (e.g. at the FFB collection ramp) in order to directly channel the clean loose fruits into a waiting lorry or a bin. This method is expected to give at least double output since the operator is able to continuously load the bags into the machine.

\section{Sound Level Measurement}

Table 4 shows the average level of noise created by the machine before and after the modifications. The average level of noise created by the machine before the modifications was $99.6 \mathrm{~dB}(\mathrm{~A})$. The highest and the lowest noise level recorded were $102.0 \mathrm{~dB}(\mathrm{~A})$ and $97.3 \mathrm{~dB}(\mathrm{~A})$, respectively. The result indicates that the highest sound level is at position No. 4, which is at the second vibrating table. This is the area where the crankshaft is located to create the vibrating action.

After modifications, there was a significant difference $(\mathrm{p}<0.05)$ in the sound levels produced by the machine. The sound levels were reduced $8.4 \%$ compared to before the modifications. Referring to Figure 5, the highest noise value was $96.3 \mathrm{~dB}(\mathrm{~A})$ that occurred at location No. 2 which is the engine. However, this value had decreased compared to before the modifications were made [101.8 dB (A)]. Noise at location No. 1, which is the place for the operator to stand during the operation was also reduced to $87.5 \mathrm{~dB}(\mathrm{~A})$.

Recommendation of exposure limits by the National Institute for Occupational Safety and Health (NIOSH) are shown in Table 5 (NIOSH, 1998). At the exposure of $91 \mathrm{~dB}(\mathrm{~A})$ and without any protective equipment, the operator of the loose 
TABLE 3. SUMMARY OF PRODUCTIVITY AND LOOSE FRUITS (LF) CLEANLINESS

\begin{tabular}{|c|c|c|c|c|c|c|}
\hline \multirow[t]{2}{*}{$(n=9)$} & \multirow{2}{*}{$\begin{array}{c}\text { Weight of LF } \\
\text { sample, } W_{1}(\mathbf{k g})\end{array}$} & \multirow{2}{*}{$\begin{array}{l}\text { Cleaning time, } \\
T_{1}(s)\end{array}$} & \multirow{2}{*}{$\begin{array}{c}\text { Weight of } \\
\text { cleaned LF, } W_{2}(\mathbf{k g})\end{array}$} & \multirow{2}{*}{$\begin{array}{l}\text { Weight of LF after } \\
\text { manually } \\
\text { cleaned, } W_{3}(\mathrm{~kg})\end{array}$} & \multicolumn{2}{|c|}{ Weight of debris, $(\mathrm{kg})$} \\
\hline & & & & & $\begin{array}{c}\text { by } \\
\text { machine, } \\
W_{1}-W_{2}\end{array}$ & $\begin{array}{c}\text { by } \\
\text { manual, } \\
\mathrm{W}_{2}-\mathrm{W}_{3}\end{array}$ \\
\hline Mean & 30.6 & 99.9 & 27.2 & 26.9 & 3.4 & 0.3 \\
\hline $\mathrm{SD}$ & 2.32 & 23.44 & 2.83 & 2.75 & 1.19 & 0.17 \\
\hline
\end{tabular}

Note: $W_{1}$ - weight of loose fruits before the cleaning process.

$\mathrm{W}_{2}$ - weight of loose fruits after the cleaning process.

$\mathrm{W}_{3}$ - weight of loose fruits after manually cleaning.

$\mathrm{T}_{1}$ - time to complete cleaning process from one bag of loose fruits.

TABLE 4. SOUND LEVELS DURING OPERATION BEFORE AND AFTER MODIFICATIONS

\begin{tabular}{llll}
\hline Location & \multicolumn{2}{c}{ Mean, $\mathbf{d B}(\mathbf{A}) \mathbf{( n = 3 )}$} & \multirow{2}{*}{$\begin{array}{c}\text { Differences } \\
\mathbf{( \% )}\end{array}$} \\
\cline { 2 - 3 } & Before & After & \\
\hline 1 & 98.5 & 87.5 & -11.2 \\
2 & 101.8 & 96.3 & -5.4 \\
3 & 99.6 & 94.8 & -4.8 \\
4 & 102.0 & 89.8 & -12.0 \\
5 & 97.3 & 88.8 & -8.7 \\
6 & 98.2 & 90.3 & -8.0 \\
\hline Mean & $99.6 \pm 2.0$ & $91.2 \pm 3.5$ & -8.4 \\
\hline
\end{tabular}

TABLE 5. AVERAGE SOUND EXPOSURE LEVELS NEEDED TO REACH THE MAXIMUM ALLOWABLE DAILY DOSE OF $100 \%$

\begin{tabular}{cc}
\hline $\begin{array}{c}\text { Time to reach } \mathbf{1 0 0} \% \\
\text { noise dose }\end{array}$ & $\begin{array}{c}\text { Exposure level } \\
\text { per NIOSH REL }\end{array}$ \\
\hline $8 \mathrm{hr}$ & $85 \mathrm{~dB}(\mathrm{~A})$ \\
$4 \mathrm{hr}$ & $88 \mathrm{~dB}(\mathrm{~A})$ \\
$2 \mathrm{hr}$ & $91 \mathrm{~dB}(\mathrm{~A})$ \\
$60 \mathrm{~min}$ & $94 \mathrm{~dB}(\mathrm{~A})$ \\
$30 \mathrm{~min}$ & $97 \mathrm{~dB}(\mathrm{~A})$ \\
$15 \mathrm{~min}$ & $100 \mathrm{~dB}(\mathrm{~A})$ \\
\hline
\end{tabular}

Note: REL - recommended exposure limits.

fruits separating machine is only allowed to work for $2 \mathrm{hr}$ per day to reduce the risk of damaging the hearing system.

For that reason, a protective equipment such as ear plug or ear muff should be provided to the operator due to high noise level to enable them to work at normal working hours and at the same ime protect their hearing and health. Under the Factories and Machinery (Noise Exposure) Regulation 1989, Part V, Regulation 17 (1) employers shall make approved hearing protectors available at no cost to all employees that exposed to noise greater than the permissible limits.

The source of the noise is mostly due to the vibrating mechanism, which is the crankshaft system. Although it produced sufficient vibration to the tables, however, the system created too much noise. Table 6 shows the summary of the advantages and disadvantages of using different vibrating mechanisms.

\section{Cost Analysis}

The following parameters and assumptions were used in cost analysis of the machine as shown in Table 7.

With an estimation of machine output at $6 \mathrm{t}$ loose fruits per day, the total operational cost for the machine for both type of usages (stationary and mobile) were calculated at RM $22.60 \mathrm{t}^{-1}$ and RM 26.37 $\mathrm{t}^{-1}$, respectively (Table 8 ). This additional cost can be justified with the extra payment received from the mill due to the higher OER. As discussed earlier, the productivity of oil palm loose fruits separating machine is also potential to be increased if used as a stationary type, hence, this should further lowering the operating cost.

\section{CONCLUSION}

The concept of debris separation from the loose fruits via a combination of double layer vibrating tables and high velocity of air is proven to be effective for separating loose fruits from debris.

However, several factors need to be considered in order to successfully recommend this machine to the oil palm industry. It was noted that the noise produced by the machine is considered high and may risk the health of the operator for long-term exposures. Safety precaution such as wearing earplug is recommended to reduce the risks. Other mechanisms to create the vibrating action also should be considered such as using an oscillating arm to change the rotation movement from the engine to the linear movement of the vibrating tables.

Along the project duration, comments from the industry were also noted and considered. The 
TABLE 6. ADVANTAGES AND DISADVANTAGES BETWEEN USING OFF-CENTRED FLYWHEEL AND CRANKSHAFT SYSTEM

\begin{tabular}{lr}
\hline \multicolumn{1}{c}{ Off-centred flywheel system } & \multicolumn{1}{c}{ Crankshaft system } \\
\hline $\begin{array}{l}\text { Advantages } \\
\text { 1. No metal to metal contact hence less noise produced }\end{array}$ & $\begin{array}{c}\text { Advantages } \\
\text { 1. Created more vibrating action } \\
\text { Disadvantages } \\
\text { 1. Created less vibrating action especially } \\
\begin{array}{l}\text { when large amount of loose fruits dumped } \\
\text { on the vibrating bed }\end{array}\end{array}$ \\
$\begin{array}{l}\text { 2. Possibility of shaft bearing broken } \\
\text { due to vibrations }\end{array}$ & $\begin{array}{l}\text { 1. Crankshaft system created noise } \\
\text { (above } 90 \mathrm{~dB})\end{array}$ \\
3. Extra weight to the machine & $\begin{array}{l}\text { Need to change the Teflon periodically } \\
\text { as the Teflon worn out after } 100 \text { hr } \\
\text { of operation }\end{array}$ \\
\hline
\end{tabular}

TABLE 7. PARAMETERS USED IN THE COST ANALYSES OF THE OIL PALM LOOSE FRUITS SEPARATING MACHINE

\begin{tabular}{|c|c|}
\hline Parameters & Remarks \\
\hline Estimated initial cost & $\begin{array}{l}\text { RM } 15000 \text { without tractor } \\
\text { RM } 55000 \text { with tractor }\end{array}$ \\
\hline Estimated operating hours $\left({\left.\mathrm{hr} \mathrm{yr}^{-1}\right)}^{-1}\right.$ & 1800 \\
\hline Working hours $\left(\right.$ day $\left.^{-1}\right)$ & 6 \\
\hline Total economic life (hr) & 9000 \\
\hline Economic life (yr) & 5 \\
\hline Salvage value & $10 \%$ of the initial cost \\
\hline Tax, shelter and insurance & $2 \%$ of the initial cost \\
\hline Interest on investment & $5 \%$ of the initial cost \\
\hline Fuel consumption $\left(1 \mathrm{hr}^{-1}\right)$ & 2 \\
\hline Fuel price (RM litre $\left.{ }^{-1}\right)$ & 2.2 \\
\hline Lubricant cost & $15 \%$ of the fuel cost \\
\hline Repair and maintenance cost $\left(\mathrm{RM} \mathrm{hr}^{-1}\right)$ & $5 \%$ of the initial cost \\
\hline Labour requirement & 1 \\
\hline Labour wages $\left(\mathrm{RM} \mathrm{man}^{-1} \mathrm{day}^{-1}\right)$ & 50 \\
\hline Machine's productivity $\left(\mathrm{t} \mathrm{day}^{-1}\right)$ & 6 \\
\hline
\end{tabular}

TABLE 8. SUMMARY OF OPERATIONAL COST OF THE OIL PALM LOOSE FRUITS SEPARATING MACHINE

\begin{tabular}{lcl}
\hline & $\begin{array}{c}\text { Stationary type } \\
\text { (without tractor) }\end{array}$ & $\begin{array}{c}\text { Mobile type } \\
\text { (with tractor) }\end{array}$ \\
\hline Estimated total machine cost $\left(\mathrm{RM} \mathrm{hr}^{-1}\right)$ & 14.27 & 18.04 \\
Estimated total machine cost $\left(\mathrm{RM} \mathrm{day}^{-1}\right)$ & 85.62 & 108.24 \\
Operational cost $\left(\mathrm{RM} \mathrm{t}^{-1}\right)$ & 22.60 & 26.37 \\
\hline
\end{tabular}

planters and millers agreed that the loose fruits have to be separated from trash in order to have better OER. Therefore, mechanisms need to be implemented to overcome this problem. Some incentives should be considered for those who send clean loose fruits at a certain percentage of debris to the mill. The mill should also consider processing the clean loose fruits separately from the FFB. A dedicated sterilisation compartment or cages for the clean loose fruits during processing should also be considered. This measure is so important and crucial to increase the national OER.

\section{ACKNOWLEDGEMENT}

The authors would like to thank the DirectorGeneral of MPOB for permission to publish this article. The authors would also like to acknowledge the Director of Biological Research, MPOB for his comments to improve this article.

\section{REFERENCES}

ABD RAHIM, S; MOHD RAMDHAN, K; MOHD SOLAH, D and AMINULRASHID, M (2012). Oil 
palm loose fruits collecting machine (MK III). $M P O B$ Information Series No. 592. palmolis.mpob.gov.my/ publication/TOT/TT-505.pdf.

AHMAD, H; AHMAD ZAMRI, M Y and MOHD SALIH, J (1995). Loose fruit collector. PORIM Information Series No. 19. palmolis.mpob.gov.my/ publication/TOT/TT-19.pdf.

AHMAD ZAMRI, M Y and MOHD ZULFAHMI, M Y (2017). Loose oil palm fruit segregating machine and method of segregating loose oil palm fruits using the same. WO 2017010862 A1.

AMIRSHAH, T and HOONG, H W (2003). Improved loose fruit collection system using sawit loose fruit separator. Proc. of the PIPOC
2003 International Palm Oil Congress - Agriculture Conference. p. 43.

DARIUS, E P and MUHAMMAD FAIRULNIZAM, $H(2014)$. Effects of collecting systems and plantation environment on debris accumulation in a collected oil palm loose fruits. Proc. of lnt. Conf. Plt. Phy. 2014. p. 147-151.

GEMKA SDN BHD (2017). Loose fruit cleaner. https: / / www.gemka.com.my/loose-fruit-cleaner, accessed on 24 March 2017.

NIOSH (1998). Criteria for a Recommended Standard: Occupational Noise Exposure. DHHS (NIOSH) Publication Number 98-126. https:// www.cdc.gov/ niosh/docs/98-126, accessed on 6 February 2017. 